\title{
WATER SAVING FOR PADDY CULTIVATION UNDER THE SYSTEM OF RICE INTENSIFICATION (SRI) IN EASTERN INDONESIA
}

\author{
Mohammad Hasan'1 and Shuichi Sato') \\ 1/Minister Advisor for Institutional Cooperation the Ministry of Public Works, Jakarta, Indonesia \\ 2)Nippon Koei Consultant Team Leader Decentralized Irrigation System Improvement Project \\ in Eastern Region of Indonesia (DISIMP), Jakarta
}

\begin{abstract}
The System of Rice Intensification (SRI) developed in Madagascar in 1980s is a revolutionary new idea for paddy cultivation to increase yields with reduced external resources. Basic idea of SRI originally proposed (Basic SRI) is to apply combination of (a) transplanting of young seedlings with wider spacing and (b) intermittent irrigation during vegetative growth period. Further, application of organic fertilizers without use chemicals has practiced as "Organic SRI" as an ideal approach to improve soil and to produce high quality rice. Over the past five years, a Japan-funded irrigation project in Eastern Indonesia executing by the Directorate General of Water Resources, the Ministry of Public Works has introduced SRI and assessed it's potential to reduce demand for irrigation water while rewarding farmers with higher production and incomes. This paper reports on on-farm comparative evaluations conducted over 9 seasons between 2002 and 2006 across 8 provinces under DISIMP. It summarizes the results of 12,133 comparison trials that covered a total area of 9,429 hectares. Average yield increase was $78 \%(3.3 \mathrm{t} / \mathrm{ha}$ ) with reductions of $40 \%$ in water use, $50 \%$ in fertilizer applications, and $20 \%$ in the costs of production. As a conclusion, SRI practices can achieve significantly higher output of rice with a reduction in inputs, enhancing simultaneously the productivity of the resources (land, labor, water and capital) used in irrigated rice production. The economic attractiveness of SRI methods is very great, giving farmers strong incentive to accept water-saving as new norm for irrigated rice production.
\end{abstract}

Keywords: System of Rice Intensification; Water saving for paddy; Intermittent irrigation; Young seedlings; Yield increase; Low input; Farmer income; Fertilizer reduction.

\section{BACKGROUND}

The first evaluations of SRI (System of Rice Intensification) in Indonesia were begun in the 1999 dry season by the Agency for Agricultural Research and Development (AARD) at its rice research center in Sukamandi, West Java. The first on-farm evaluations of SRI were done in 2001 in Ciamis district, West Java, through a Farmer Field School there that was part of the national integrated pest management (IPM) program. This initiative has continued mainly by Mr. Alik and his group in Ciamis district so as to disseminate Organic SRI in and around the region since 2002. In 2007 a total of 9,829 farmers $(2,848 \mathrm{ha})$ has practiced Organic SRI successfully mainly in West Java. Starting in 2002, Basic SRI was introduced in Eastern Indonesia under the auspices of DISIMP (Decentralized Irrigation System Improvement Project in Eastern Region of Indonesia) with a Japanese loan, being executed by the Directorate General of Water Resources of the Ministry of Public Works.

\section{OUTLINE OF BASIC SRI IN DISIMP SCHEMES \\ Characteristrices of SRI}

In its introduction and evaluation of SRI, DISIMP took a approach to adapt the usually recommended SRI methods to local conditions. The basic concepts and practices that constitute SRI start with transplantation of young seedlings (7-14 days old), singly (not in clumps), and widely spaced $(30 \mathrm{~cm} \times 30 \mathrm{~cm})$. Then, irrigation water is applied intermittently with no continuous flooding of the paddies. Whenever rice paddies are not kept flooded, weed control measures are more necessary. For introduction of SRI, DISIMP has focused on achieving water-savings and enhancing farmer incomes quickly. The respective SRI and standard farmer practices used in the yield are described in Table 1. 
Table 1. Standard Paddy Cultivation Practices for SRI and Conventional Method under DISIMP Irrigation Schemes

\begin{tabular}{|c|c|c|}
\hline Practices & SRI methods under DISIMP & Conventional methods (irrigated) \\
\hline $\begin{array}{l}\text { Land preparation } \\
\text { (LP) }\end{array}$ & $\begin{array}{l}2 \text { times: } I^{\text {st }} L P \text { for plowing, and } \\
2^{\text {nd }} L P \text { for puddling and leveling } \\
\text { No standing water after } 2^{\text {nd }} L P\end{array}$ & $\begin{array}{l}2 \text { times: } 1^{\text {st }} \mathrm{LP} \text { for plowing, and } \\
2^{\text {nd }} \mathrm{LP} \text { for puddling and leveling } \\
\text { Standing water after } 2^{\text {nd }} \mathrm{LP}\end{array}$ \\
\hline Seed & & \\
\hline $\begin{array}{l}\text { - Quality } \\
\text { - Quantity }\end{array}$ & $\begin{array}{l}80-100 \% \text { certified seed } \\
\text { Transplanting@ } 5-8 \mathrm{~kg} / \mathrm{ha}\end{array}$ & $\begin{array}{l}20-40 \% \text { certified seed } \\
\text { Transplanting @ 30-50 kg/ha, }\end{array}$ \\
\hline $\begin{array}{l}\text { - Seedling age } \\
\text { Transplanting }\end{array}$ & $8-12$ days at transplanting & 21-30 days at transplanting \\
\hline - Seedling no. & $\begin{array}{l}\text { I seedling in each hill, transplanted at } \\
1-2 \mathrm{~cm} \text { depth }\end{array}$ & $\begin{array}{l}\text { 3-5 seedlings in each hill, plunged into soil, variable } \\
\text { depth }\end{array}$ \\
\hline $\begin{array}{l}\text { - Spacing } \\
\text { Irrigation }\end{array}$ & $30 \times 30 \mathrm{~cm}$ with regular distances & 15 to $20 \mathrm{~cm}$ at random intervals \\
\hline $\begin{array}{l}\text { - Vegetative } \\
\text { growth stage }\end{array}$ & $\begin{array}{l}\text { Intermittent irrigation with wet-dry cycle, } \\
\text { with only shallow standing water during } \\
\text { wet periods }( \pm 2 \mathrm{~cm})\end{array}$ & $\begin{array}{l}\text { Continuous irrigation, keeping } 5-10 \mathrm{~cm} \text { of standing } \\
\text { water on fields }\end{array}$ \\
\hline $\begin{array}{l}\text { - Reproductive } \\
\text { stage }\end{array}$ & $\begin{array}{l}\text { Continuous irrigation, keeping } 2-5 \mathrm{~cm} \text { of } \\
\text { standing water }\end{array}$ & $\begin{array}{l}\text { Continuous irrigation, keeping } 5-10 \mathrm{~cm} \text { deep } \\
\text { standing water }\end{array}$ \\
\hline Weeding & & \\
\hline - Method & $\begin{array}{l}\text { Rotary weeder, weeding tools, or manual } \\
\text { weeding }\end{array}$ & Weeding tools, or manual weeding \\
\hline $\begin{array}{l}\text { - Frequency } \\
\text { Fertilizer use }\end{array}$ & $2-3$ times in vegetative growth stage & $1-2$ times in vegetative growth stage \\
\hline $\begin{array}{l}\text { - Type } \\
\text { - Amount }\end{array}$ & $\begin{array}{l}\text { Chemical fertilizer ( } 50 \% \text { reduction) } \\
\text { Recommend } 150 \mathrm{~kg} / \mathrm{ha} \text { urea and } \\
100 \mathrm{~kg} / \mathrm{ha} \text { SP } 36 . \text { Otherwise farmers still } \\
\text { follow guidelines of the district } \\
\text { agricultural office }\end{array}$ & $\begin{array}{l}\text { Chemical fertilizer as recommended by Dept. of } \\
\text { Agriculture } \\
\text { Follow guidelines of the district agricultural office }\end{array}$ \\
\hline
\end{tabular}

\section{EVALUATIONS OF SRI PROGRESS}

Under DISIMP, the expansion of SRI trials over 9 seasons, with their extent and yield results shown by season, is summarized in Table 2. The trials during the first five seasons were not many, and often hesitant, but the results were impressive enough that this initial trial period was followed by an extension period, in which even more significant yield and resource-saving advantages were documented as farmers gained skill and confidence in the methods.

Table 2. Extension of SRI methods under DISIMP in 2002-2006

\begin{tabular}{|c|c|c|c|c|c|}
\hline \multirow{2}{*}{$\begin{array}{c}\text { Cropping } \\
\text { season }\end{array}$} & \multirow{2}{*}{$\begin{array}{l}\text { Number of } \\
\text { farmers }\end{array}$} & \multirow{2}{*}{$\begin{array}{c}\text { SRI } \\
\text { harvested area } \\
\text { (ha) }\end{array}$} & \multicolumn{3}{|c|}{ Average paddy yield * } \\
\hline & & & $\begin{array}{c}\text { SRI } \\
\left(\mathrm{t} / \mathrm{ha}^{-1}\right)\end{array}$ & $\begin{array}{c}\begin{array}{c}\text { Non-SRI } \\
\left(t / h^{-1}\right)\end{array} \\
\text { (n) }\end{array}$ & $\begin{array}{c}\text { Increase } \\
(\%)\end{array}$ \\
\hline \multicolumn{6}{|l|}{ Trial stage } \\
\hline 2002 & 1 & 0.10 & 5.58 & 4.31 & 29.5 \\
\hline $2002 / 2003$ & 12 & 3.40 & 7.39 & 4.76 & 55.2 \\
\hline 2003 & 1 & 0.16 & 8.39 & 4.67 & 79.7 \\
\hline $2003 / 2004$ & 8 & 5.62 & 7.77 & 4.18 & 85.8 \\
\hline \multicolumn{6}{|l|}{ Extension stage } \\
\hline 2004 & 21 & 12.16 & 7.23 & 4.06 & 77.8 \\
\hline $2004 / 2005$ & 522 & 387.37 & 7.90 & 4.09 & 92.9 \\
\hline 2005 & 1,336 & $1,016.70$ & 6.85 & 3.89 & 75.9 \\
\hline $2005 / 2006$ & 5,258 & $4,245.46$ & 7.98 & 4.63 & 72.4 \\
\hline 2006 & 4,974 & $3,758.13$ & 7.39 & 4.04 & 82.8 \\
\hline Total / Average & 12,133 & $9,429.10$ & 7.61 & 4.27 & 78.0 \\
\hline
\end{tabular}

* As noted in Table 2, this scheme experienced irrigation water stoppage in the 2006 season. 
From the table, it is seen that the first-season results from SRI methods were not very impressive; but the team continued with its trials nevertheless. After SRI effects were confirmed on a larger scale during subsequent trials in 2003 and 2004, the project formulated a strategy for reducing water requirements and increasing farmer incomes through SRI promotion. Core groups for SRI extension under DISIMP were formed by the team's agronomists and SRI facilitators. Good cooperation was realized with local government officials such as agricultural officers and extension officers. Subsequently, dissemination of SRI was started in several locations by farmer themselves outside the project area (farmer-to-farmer spread), including in Bali. Although SRI areas have begun to extend rapidly under DISIMP, the rate of progress of extension has varied among schemes.

The records of SRI practice have been collected by the consultants' agronomists and SRI facilitators in cooperation with local government extension officials for documenting key practices including (a) method of seedling preparation, (b) age of seedling for transplanting, (c) rice variety used, (d) transplanting spacing, (e) weeding method and number of weedings, ( $f$ ) intermittent irrigation cycle, and (g) type and amount of fertilizer applied. The recommended SRI practices listed in Table 1 were fully followed by SRI farmers except for fertilizer applications.

Non-SRI plots for sampling were selected nearby SRI plots served by the same tertiary canal managed by the same Water Users' Association. Rice variety was the same for both SRI and non-SRI plots in all cases. Physical conditions for measuring plots including soil type and topography as well as weather conditions were the same for both SRI and non-SRI plots.

\section{YIELD COMPARISON}

Average yields of paddy (dry unhusked rice) for the entire extent of trials $(9,429$ ha) was 7.61 tha for SRI cultivation, which was $78 \%$ higher than the yield for conventional (non-SRI) methods of $4.27 \mathrm{t} / \mathrm{ha}$, as seen in Table 2. All reported weights were adjusted to a standard $14 \%$ moisture content, as noted above. Definite regional differences were observed within Eastern Indonesia. Paddy yields in Nusa Tenggara province were $8.02 \mathrm{t} /$ ha for SRI vs. 4.19 tha for non-SRI methods, a $91.4 \%$ increase on 2,450 ha. In Sulawesi, on the other hand, average SRI yield was 7.44 tha vs. 4.32 tha for non-SRI rice crop, an increase of $71.3 \%$ on 6,979 ha. Average yields analyzed by cropping season showed wet-season yields to be higher than dryseason yields for both SRI and non-SRI. However, the percentage yield increases with SRI were somewhat higher in dry-season cropping, also seen from that table. SRI methods were thus relatively more beneficial in the dry season, perhaps because it is easier to maintain aerobic soil conditions. We also see from this table that SRI yields were, on average, higher in Nusa Tenggara than Sulawesi, possibly reflecting drier conditions in Nusa Tenggara.

\section{LESSONS LEARNED OF SRI PRACTICE}

One conclusion from DISIMP experience is that the SRI method is not a conventional agricultural technology innovation; rather it is a whole cultivation system that involves the integration of technical, managerial, social and agronomic factors:

- Good irrigation infrastructure is essential for efficient operation and maintenance, as is the active participation by farmers in making adjustments and dissemination.

- Good management and O\&M of irrigation schemes by administrative staff is essential to get the farmer participation that facilitates water-sharing and intermittent irrigation.

- Strong and vigorous farmer groups, dynamically interacting and participating in O\&M of the main system, are essential for undertaking rigorous intermittentirrigation regimes.

- Motivated farmers are important, with high levels of agricultural skills and an acute awareness of possibilities for innovation and increasing their yields and crop area. Otherwise, agricultural conservatism will prevail, and present practices will continue.

Extension of Basic SRI is likely to be quickest and most successful in schemes where the above-listed factors are present. The process works best if farmer-driven, and it should proceed at a pace and rate that farmers are comfortable with, rather than promote SRI in a top-down campaign. Adaptations should always be encouraged to suit local conditions. Experience in DISIMP and other countries indicates that the introduction of SRI itself helps to improve farmers' motivation and desire for new knowledge and skills. Once they see that their previous practices, in which they have had so much confidence, can be surpassed by simple but profound changes in their methods of production, this is a real mind-opener, for many if not all.

Farmer-to-farmer dissemination is possible and desirable with SRI because this innovation does not rely on external inputs, only on new knowledge and altered attitudes. In addition to farmer efforts and field trials and research from the government and NGO side, the uptake of SRI will benefit from publicity campaigns by poster, lectures, and other means of communication, not only at the field level, but from all national, regional and local governments involved with paddy rice cultivation, creating a widespread awareness of the opportunities presented by these new understandings of optimizing rice production.

\section{IRRIGATION METHODS FOR SRI}

\section{Intermittent Irrigation}

The usual recommendation for SRI is altemate wetting and drying of fields, flooding them and then letting them drain, with a maximum depth of $2 \mathrm{~cm}$ standing water. The best length for the dry period between floodings differs by location according to soil condition (permeability, water- 
holding capacity), plot size and shape, availability of irrigation water, rainfall pattern, etc. In DISIMP schemes, the dry period for intermittent irrigation has been decided empirically. The indicator for resuming irrigation is determined visually, by the appearance of cracks of certain sizes on the surface of paddy field soils. In practice, the length of wet and dry periods and their relative proportions is influenced by the availability of irrigation water, especially in the dry season. If paddy soil is heavy clay, care must be taken not to let the soil dry out too much before rewetting, or solidified soil structure can become a hindrance to plant growth.

The actual practice for intermittent irrigation for SRI can be quite variable as seen from DISIMP experience in Table 3. For example, Jurang Baru scheme located in the downstream area of a large integrated irrigation system in Lombok, West Nusa Tenggara, had limited irrigation water supply in the 2006 dry season. There the intermittent cycle became 1 day of irrigation followed by 14 days with no irrigation.

Table 3. Examples of actual practice of intermittent irrigation for SRI under DISIMP schemes in 2006 (dry season)

\begin{tabular}{llccc}
\hline & \multicolumn{1}{c}{ Scheme } & SRI area & \multicolumn{2}{c}{$\begin{array}{c}\text { Intermittent irrigation } \\
\text { (alternating periods) }\end{array}$} \\
\cline { 3 - 5 } Province & \multicolumn{1}{c}{ (ha) } & Irrigation (days) & No irrigation (days) \\
\hline West Nusa Tenggara & Jurang Batu (Lombok) & 100 & 1 & 14 \\
& Tiu Kuli (Sumbawa) & 41 & 8 & 7 \\
& Batu Bulan (Sumbawa) & 73 & 6 & 4 \\
East Nusa Tenggara & Moyo Kanan (Sumbawa) & 645 & 8 & 7 \\
South Sulawesi & Malaka (Timor) & 48 & 10 & 4 \\
& Sadang & 344 & 8 & 6 \\
Central Sulawesi & Kelara Karalloe & 277 & 4 & 3 \\
& Tabo Tabo & 23 & 8 & 4 \\
\hline
\end{tabular}

\section{EXPERIMENT ASSESSING IRRIGATION WATER REQUIREMENTS}

To obtain precise measurements of water use when using SRI cultivation methods in comparison with non-SRI practice, a SRI experimental station was established in Lombok island. Soil condition in this station is sandy loam. The first measurement of water consumption for SRI versus
non-SR was started in test plots in the station in October 2005. To compare the effects of irrigation interval on paddy yields between SRI and non-SRI cultivation, conditions of both SRI and non-SRI lots were arranged to be equal. Applications of chemical fertilizers were at the same level for both plots ( $200 \mathrm{~kg} / \mathrm{ha}$ of urea, $36 \mathrm{~kg} / \mathrm{ha}$ of TSP, and 50 $\mathrm{kg} / \mathrm{ha}$ of $\mathrm{KCl}$ ).

Table 4. Field tests of intermittent irrigation for SRI and non-SRI practices at Lombok Experimental Station in $2005 / 2006$

\begin{tabular}{|c|c|c|c|c|}
\hline & Case-1 & Case-2 & Case-3 & Case-4 \\
\hline Transplanting method & SRI & SRI & Non-SRI & Non-sri \\
\hline Variety of rice & Ciherang & Ciherang & Ciherang & Ciherang \\
\hline Seedlings (age after seeding) & 10 days & 10 days & 25 days & 25 days \\
\hline Number of plants/hill & 1 & 1 & 4 & 4 \\
\hline Spacing & $30 \times 30 \mathrm{~cm}$ & $30 \times 30 \mathrm{~cm}$ & $20 \times 25 \mathrm{~cm}$ & $20 \times 25 \mathrm{~cm}$ \\
\hline Irrigation method (vegetative stage) & Intermittent & Intermittent & Continuous & Intermittent \\
\hline Wet period & 5 days & 10 days & & 10 days \\
\hline Dry period & 10 days & 5 days & & 5 days \\
\hline Irrigation method (reproductive stage) & Continuous & Continuous & Continuous & Continuous \\
\hline \multicolumn{5}{|l|}{ Planting schedule } \\
\hline Date of transplanting & 11 Oct. 2005 & 11 Oct. 2005 & 26 Oct. 2005 & 26 Oct. 2005 \\
\hline Date of harvest & 3 Feb. 2006 & 4 Feb. 2006 & 3 Feb. 2006 & 4 Feb. 2006 \\
\hline \multicolumn{5}{|l|}{ Results of measurement } \\
\hline Total amount of irrigation water & $816 \mathrm{~mm}$ & $1,152 \mathrm{~mm}$ & $1,368 \mathrm{~mm}$ & $1,136 \mathrm{~mm}$ \\
\hline Padḑy yield (dry un-husked rice) & $5.12 \mathrm{t} / \mathrm{ha}$ & $4.46 \mathrm{t} / \mathrm{ha}$ & $2.95 \mathrm{t} / \mathrm{ha}$ & $3.40 \mathrm{t} / \mathrm{ha}$ \\
\hline
\end{tabular}

Although the observation data are limited and further observations are being conducted, the following findings can be reported from the results above.
- The SRI method can definitely offer higher paddy yields than non-SRI practices; there was a $75 \%$ increase with SRI in these trials. 
- SRI paddy yields decrease when the dry periods are shorter, and they increase when the dry periods are longer.

- If intermittent irrigation is applied to non-SRI plots, paddy yield can be increased by 15\% compared with continuous flow irrigation. (compare case- 3 with case-4)

- Higher paddy yields by SRI over non-SRI cultivation may be the result of the combined effects of (a) SRI transplanting practices, and (b) intermittent irrigation with sufficient dry periods.

- The water-saving potential of SRJ (intermittent irrigation during the vegetative growth stage) versus non-SRI cultivation (continuous irrigation) will justify $\sim 40 \%$ reduction in water consumption at the field level during the growing stage.

- Further savings may be found possible if experiments show that continuing some form of reduced irrigation during the reproductive stage is feasible.

\section{WATER-SAVING EFFECTS OF SRI}

According to the observations on irrigation water use with SRI cultivation in DISIMP schemes and considering the test results reported above, it can be suggested that the SRI water-saving effects are achieved by a combination of the following three factors.

- Water-saving during land preparation: Land preparation (LP) is usually performed twice for both methods. The first LP method and amount of irrigation water supplied shows no difference between SRI and non-SRI. However, the second LP operation (puddling) uses more water for non-SRI paddy fields due to the practice of keeping standing water 5 to $10 \mathrm{~cm}$ deep. With SRI cultivation, standing water after the second LP is not necessary. The total amount of water savings at this stage is estimated to be about $800-1,000 \mathrm{~m}^{3}$ per ha.

- Water-saving during nursery preparation: For non-SRI transplanting, mature seedlings of 25-30 days age are used. Nursery beds are commonly set at the corner of the main paddy field for easy transportation of large-sized seedlings. To supply water to nursery beds for one month, it is necessary to supply irrigation water to the whole paddy field continuously. The total amount of irrigation water supplied during nursery preparation is estimated to be $2,000-3,000 \mathrm{~m}^{3}$ per ha. Only a small fraction of this amount of water is necessary for SRI nursery management.

- Water-saving by intermittent irrigation: Water consumption during the rice plants' growing season after transplanting is much less for SRI than for non-SRI practices. Through field tests and observations, the reduction is about $40 \%$. In general, dry periods for intermittent irrigation should be shorter for permeable soils due to their lesser moisture-holding capacity. On the other hand, it is possible to extend dry periods longer with less permeable soils or with soils that have greater moisture-holding capacities. There can be more watersaving on such soils compared with permeable soils. As the application of organic fertilizer (compost) can improve the moisture- holding capacity of soils, this can also contribute to more water-saving. With the better plant root systems established by SRI methods, we may find it possible to extend intermittent irrigation beyond panicle initiation without sacrifice in yield, thereby achieving further water-saving.

\section{CONCLUSIONS}

The main lessons learned from three years of experience with SRI cultivation in DISIMP schemes in eastern Indonesia are as follow:

- SRI methods can offer higher paddy yields with lower production costs (seeds, chemical fertilizers, pesticides), therefore generating higher profits to farmers.

- The labor burden is increased with SRI, at least initially. However, farmers are willing to overcome this disincentive by considering the countervailing positive incentives arising from the much higher productivity of SRI paddy cultivation.

- Higher paddy yields can be obtained with SRI methods without using organic fertilizers, i.e., just with reduced chemical fertilizer use. While the use of organic sources of nutrients is preferable, this is not a necessary component of SRI. Biomass for composting or mulching is often not available, so if the use of organic fertilizers is made a requirement for SRI, its expansion under current conditions is limited. Organic fertilization should be regarded as a desirable option but not as a prerequisite to practice SRI.

- SRI cultivation saves water lowering crop water consumption requirements by $40 \%$ (variable by soil and field conditions) by applying intermittent irrigation. However, farmers will never agree to let their fields dry out without having reliable, assured access to water sources. Therefore, the introduction of SRI at the initial stage should be within irrigation areas that are in relatively good operating conditions so that SRI extension can proceed smoothly.

- For successful introduction of SRI, the involvement of local government offices as well as of experts (consultants) is necessary for giving good technical support and advice.

The water-saving effects of SRI cultivation -- more or less $40 \%$ vs. non-SRI practices -- has been confirmed by field tests as well as by field observations in many SSIMPDISIMP schemes sites. Unfortunately, SRI paddy plots and non-SRI paddy plots are mixed within these scheme areas like "patch work." This makes it difficult for farmers to control - and to minimize - their water applications as recommended. If all the paddy fields served by a single offtake were to be cultivated with SRI methods, it should be possible to reduce the amount of water distribution considerably more than achieved this far.

Until entire command areas practice SRI, the following measures are preferable for introduction to realize equitable water distribution and more efficient use of valuable water resources within irrigation schemes.

- Many irrigation systems have a common problem of inequitable water distribution, i.e. the over-tapping of channel flows by upstream users resulting in water shortages downstream. The introduction and expansion 
of SRI in the upstream areas of schemes has the potential to generate irrigation benefits for downstream users by decreasing the water consumption of upstream farmers, and thus increasing the amount of water available for downstream areas. Thus, more sustainable and equitable water distribution within irrigation schemes can be achieved through farmers' participation in SRI, what can be called a "sustainable participatory water-saving approach."

- The expansion of SRI should be particularly attractive with groundwater irrigation. Since such water is relatively more expensive, the reduction in irrigation water requirements that SRI practices permit will be more significant economically. At the same time that pump irrigation technology makes possible more precise water control and application, SRI is creating incentives to reduce water use. This will be important where groundwater extraction is currently excessive and is lowering water tables.

- For dam or pond irrigation schemes, palawija (non-rice) crops are usually recommended during the dry season to obtain more efficient use of the limited, expensive water. However, farmers have a predisposition to plant paddy during the dry season anyway, even though extension offices advise them otherwise. Due to the fact that water consumption under SRI is much less than for non-SRI cultivation, farmers can be allowed to plant paddy even in the dry season on condition that SRI methods are utilized.

The possibilities that SRI is opening up to raise the production of land, labor, capital and especially water used in irrigated rice cultivation should enable farmers, planners, technicians and policy-makers to refashion this sector in ways that are more beneficial, equitable and sustainable.

Achieving this potential will require further improvements in irrigation infrastructure and management capacities, to give farmers and water managers the ability to utilize smaller but reliable amounts of water as needed for the sustenance of crops and beneficial soil organisms. It will also require rethinking and strengthened capacities for research and extension programs and for appropriate policy formulation and implementation in the agricultural sector.

The environmental implications of such changes and redirections have not been addressed here, but one can foresee only advantages, and no disadvantages, for the conservation of natural ecosystems and biodiversity from reducing the 'thirstiness' of irrigated rice cultivation.

\section{REFERENCES}

Sato, S. 2005. "SRI as Earth-Friendly Revolution in Rice Cultivation". Article for International Development Journal Japan, December.

Uphoff, N., S.Y. Koma, Gypmantasiri, P, Prinz, K. and Kabir H. 2000. "The System of Rice Intensification (SRI) and Its Relevance for Food Security and Natural Resources Management in Southeast Asia". Paper for the International Symposium on Sustaining Food Security and Managing Natural Resources in Southeast Asia: challenges for the $21^{\text {st }}$ Century, Chiang Mai, Thailand, January 8-11.

Uphoff, N. and R. Randriamiharisoa. 2002. "Reducing water use in irrigated rice production with the Madagascar System of Rice Intensification". WaterWise Rice Production: Proceedings of the International Workshop on Water-Wise Rice Production, 8-11.

Uphoff, N. 2004. "SRI - System of Rice Intensification: An Opportunity for Raising Productivity in the $21^{\text {st }}$ Century: Paper for International Year of Rice Conference". FAO, Rome. February 12-13, 2004.

Uphoff, N. 2006. "The System of Rice Intensification (SRI) as a Methodology for Reducing Water Requirements in Irrigated Rice Production". Paper for International Dialogue on Rice and Water: Exploring Options for Food Security and Sustainable Environment, IRRI, Los Bańos, Philippines, March 7-8. 